DOI: $10.1515 /$ pts-2016-0042

\title{
LIFECYCLE ANALYSIS OF DIFFERENT MOTORS FROM THE STANDPOINT OF ENVIRONMENTAL IMPACT
}

\author{
S. Orlova ${ }^{1}$, A. Rassõlkin ${ }^{2}$, A. Kallaste ${ }^{2}$, T. Vaimann ${ }^{2,3}$, A. Belahcen ${ }^{3}$. \\ ${ }^{1}$ Institute of Physical Energetics, \\ 11 Krivu Street, LV-1006, Riga, LATVIA \\ ${ }^{2}$ Tallinn University of Technology \\ 5 Ehitajate Tee, 19086, Tallinn, ESTONIA \\ ${ }^{3}$ Aalto University \\ P.O. Box 11000, FI-00076, Aalto, FINLAND
}

\begin{abstract}
Comparative analysis is performed for different motors from the standpoint of damage inflicted by them during their lifecycle. Three types of motors have been considered: the synchronous reluctance motor, the permanent magnet assisted synchronous reluctance motor and the induction motor. The assessment of lifecycle has been made in terms of its four stages: manufacturing, distribution, use and end of life. The results show that the production costs of synchronous reluctance motor are lower compared to that of permanent magnet assisted motors, but due to their low efficiency they exert the greatest environmental impact. The main conclusion is that the assessment made at the early designing stage for the related environmental impact enables its reduction.
\end{abstract}

Keywords: environmental impact, induction motor, lifecycle assessment, permanent magnets, synchronous reluctance motor.

\section{INTRODUCTION}

Electric motors consume $43 \%-46 \%$ of global electricity, which means about $6040 \mathrm{Mt} \mathrm{CO}_{2}$ emissions per year [1]. In this paper, an electric motor is defined as a device that converts electric energy into mechanical energy. As part of the coordinated efforts throughout the world to reduce the energy consumption and $\mathrm{CO}_{2}$ emissions the regulation authorities in many EU countries have introduced the ICE 60034-30-1:2014 regulation to stimulate the production and use of high-efficiency motors [2]. Toughening the energy efficiency requirements leads to the search and development of alternative technologies for electric motors. However, the manufacturing of diversified products and services causes the ecological crisis. During their entire lifecycle, these products contribute repeatedly to the environmental pollution. Nowadays, improving the efficiency of the electric motor goes on concurrently with a decrease of harmful emissions arising at the phases of production, use, and dispos- 
al. Therefore, a topical issue is the product lifecycle assessment (LCA), whose main principles are defined by the International Organisation for Standardisation: ISO 14040 and ISO14044 standards [3], [4]. The former (ISO 14040 standard) presents the introduction into the LCA and describes its applicable specifications, containing also the reference information, while the latter (ISO 14044 standard) regulates the LCA performance process.

\section{LIFECYCLE ASSESSMENT}

The lifecycle assessment implies important procedures that can help reduce motor impact on the environment, thus being an instrument for assessment of the influence exerted by particular products on the environment - from cradle to grave beginning with acquisition of the materials followed by manufacturing, transporting, marketing, use and recycling. Similar to other products, in the motor lifecycle four stages could be distinguished (see Fig. 1).

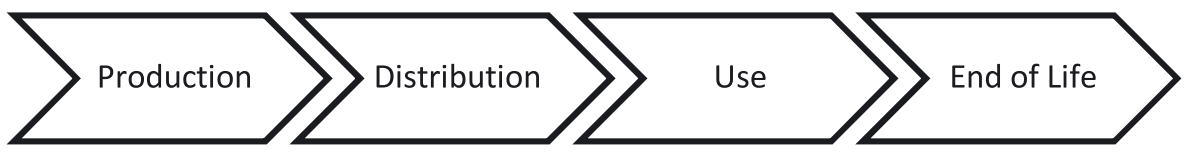

Fig. 1. Four stages in the product lifecycle.

The production stage. Pollution of the environment begins with extraction of natural resources. Therefore, the first stage includes the extraction of natural resources and energy sources from the Earth. Transportation of the basic material prior to its processing also belongs to this stage, followed by the processing of the raw material and obtaining of the final product. For the production of electric machines, the following materials are used: winding electrical copper, sheet steel, impregnating varnishes and compounds, cover enamels, as well as widely diversified materials of the electrical insulation (paper, cardboard, polyester films and ribbons, stratified plastics, plastic material, mica, asbestos). To produce an electric motor, the general machine industry technological processes are applied. Figure 2 shows a block diagram of producing of electric machine.

The distribution stage includes all technological processes needed for packing and transportation of the final product. The energy and ecological waste caused by transportation to the shopping units or to the customer are taken into account within this stage of lifecycle.

The use stage is the longest and the most expensive stage within the lifecycle of an electric machine. This stage is mostly associated with the customer: the actual use, the repeated use, and the service life of the product. The energy needs and ecological waste are included in the use stage due to storage and consumption. At this stage, the operational efficiency of electric motor is especially important. The main parameters of a motor are its output power and efficiency. Therefore, it should be properly designed not only because of economic reasons, but also due to ecological aspects. The electric motors are generally designed for the lifespan of 15-20 years without overhaul under the condition of their normal operation. At the use stage, pol- 
lution is mainly caused by overheat, generation of external magnetic fields, noise, vibration, emissions of volatile substances from electrical materials. It should be noted that when the power of the electric machine is higher, the values of these polluting parameters are also higher [7]. The use stage of MEEUP model also includes trips for repair and maintenance as the distance covered over the motor life $(250 \mathrm{~km})$.

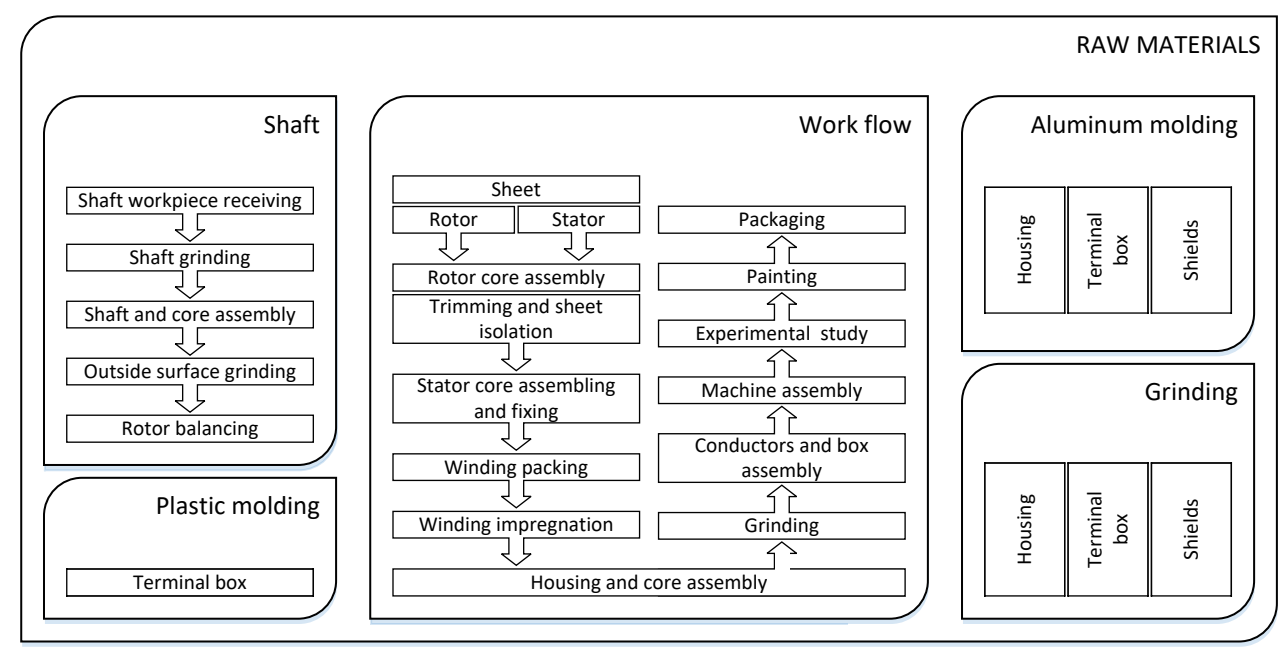

Fig. 2. Block diagram of manufacturing of the electric machine.

End of life means that the state of an electrical machine has reached the end of its first use until its final disposal. The end of life stage includes the energy needed for recycling the product as well as waste recycling, composting and burning in compliance with the relevant regulation.

The main reasons for making LCA are as follows:

- willingness to collect the information about the ecological influence of the product or service in order to find the possibilities to reduce the environmental impact;

- necessity to explain to the consumer the best methods of application of the product and its recycling;

- collection of the information on the receipt of eco-certificates;

- comparison of the environmental impact made by different products.

\section{RESULTS OF THE COMPARATIVE ANALYSIS AND DISCUSSION}

The comparison was performed in view of the related environmental impact. For its assessment many methodological approaches have been developed (Table 1) [8], [9]. In the present research, the Methodology for the Ecodesign of Energy-using Products (MEEuP) is applied, which has been worked out to determine whether and to what extent a product meets the criteria stipulated in the Directive on the Ecodesign of Energy-using Products (EuP 2005/32/EC) [5]. 
The MEEuP analysis requires these inputs [10]:

- bill of materials and manufacturing processes;

- performance, consumption and emission characteristics during the use phase;

- distribution characteristics: volume of package final product, transport mix;

- $\quad$ end-of-life characteristics: recycling and waste disposal.

Table 1

The List of Methodologies for LCA

\begin{tabular}{|l|l|l|}
\hline Methodology & Developed by & Country of origin \\
\hline CML 2002 & CML & The Netherlands \\
\hline Eco-indicator 99 & PRé & The Netherlands \\
\hline EDIP97-EDIP2003 & DTU & Denmark \\
\hline EPS 2000 & IVL & Sweden \\
\hline Impact 2002+ & EPFL & Switzerland \\
\hline LIME & AIST & Japan \\
\hline LUCAS & CIRAIG & Canada \\
\hline ReCiPe & RUN+ PRé+CML+RIVM & The Netherlands \\
\hline Swiss Ecoscarcity 07 & E2+ESU-services & Switzerland \\
\hline TRACI & US EPA & The USA \\
\hline MEEuP & VhK & The Netherlands \\
\hline
\end{tabular}

The MEEuP methodology provides a tool for estimation of the environment impact. At the preparatory phase, the economic, material and energy use data were collected for inputting to a relevant model at different stages of a product lifecycle. The model translates these inputs into quantifiable environmental impacts.

The results of MEEuP analysis are presented as a list of environmental indicators [10]:

- $\quad$ energy, water (process and cooling);

- $\quad$ waste (hazardous and non-hazardous);

- global warming potential (GWP);

- acidification potential;

- $\quad$ volatile organic compounds (VOCs);

- $\quad$ persistent organic pollutants (POPs);

- $\quad$ heavy metals (to air and water);

- $\quad$ polycyclic aromatic hydrocarbons (PAH);

- $\quad$ particulate matter (PM);

- $\quad$ eutrophication potential of certain emissions to water (EP);

- ozone depletion potential.

In the present research, the lifecycle assessment has been performed for three 
types of motors: synchronous reluctance motor (SynRM), permanent magnet assisted synchronous reluctance motor (PMSynRM), and induction motor (IM).

Table 2 presents the materials used for motor manufacturing obtained by using geometric modelling of the reference motors. The motors of the 1 st and 2 nd type are similar in design, with the only difference that PMSynRMs have high-energy permanent magnets in the rotor air barriers. It should be noted that the available permanent magnets make the design heavier and much more expensive. The input data on induction motors are taken from the EuP base case [6]. The major materials used for electric motors (e.g., steel, aluminium, copper) are recyclable and have a very high value; therefore, they are recycled at the end of life.

Table 2

Bill of Materials for Motor Production

\begin{tabular}{|l|c|c|c|}
\hline \multirow{2}{*}{ Material } & \multicolumn{3}{|c|}{ Weight (kg) } \\
\cline { 2 - 4 } & SynRM & PMSynRM & IM \\
\hline Electrical steel & 34.900 & 34.900 & 36 \\
\hline Other steel & 2.110 & 2.110 & 9.500 \\
\hline Aluminium & 12.764 & 12.764 & 13 \\
\hline Copper & 6.546 & 6.546 & 6.400 \\
\hline Insulation material & 0.200 & 0.200 & 0.200 \\
\hline Permanent magnets & - & 0.710 & - \\
\hline Impregnation resin & 0.470 & 0.470 & 1 \\
\hline Paint & 0.302 & 0.302 & 0.500 \\
\hline Packing material & 9 & 9 & 9 \\
\hline
\end{tabular}

Some design recommendations can be made to improve the environmental impact of electric motors, namely [6]:

- motors should be easily assembled and disassembled;

- a reduction of the diversity of materials used should be sought;

- a reduction of non-recyclable parts, namely plastic, should be sought;

- windings should be easily removed.

Table 3 presents the parameters important for the use stage: the lifetime of a motor (taken 15 years), its operating hours, efficiency, and output power.

Table 3

Parameters Important for the Use Stage of Motors

\begin{tabular}{|l|l|l|l|}
\hline \multirow{2}{*}{ Parameter } & Value & PMSynRM & IM \\
\cline { 2 - 4 } & SynRM & 15 & 15 \\
\hline Lifetime (years) & 15 & 3000 & 3000 \\
\hline Operating hours & 3000 & 90 & 87.6 \\
\hline Efficiency (\%) & 70 & 10 & 10 \\
\hline Output power (kW) & 10 & & \\
\hline
\end{tabular}


Table 4 presents the indicators of the environmental impact made by the motors (lifetime 15 years, operation $3000 \mathrm{~h}$ ) during their lifecycle. The lifecycle indicators are divided into three blocks: main indicators, emissions into air and emissions into water.

Table 4

Lifecycle Indicators of the Environmental Impact Made by the Motors

\begin{tabular}{|l|c|c|c|}
\hline Main indicators & SynRM & PMSynRM & IM \\
\hline Total energy GER $^{(1)}(\mathrm{MJ})$ & 677883 & 531180 & 546584 \\
\hline of which, electricity (in primary MJ) & 673562 & 526625 & 541570 \\
\hline Water process (ltr) & 47740 & 37972 & 38894 \\
\hline Water cooling (ltr) & 1793733 & 1401174 & 1439963 \\
\hline Waste, non-hazardous landfill (g) & 961094 & 792773 & 838025 \\
\hline Waste, hazardous incineration $(\mathrm{g})$ & 15967 & 12582 & 13388 \\
\hline
\end{tabular}

\begin{tabular}{|l|c|c|c|}
\hline Emissions into air & SynRM & PMSynRM & IM \\
\hline $\begin{array}{l}\text { Greenhouse gases in GWO 100 (2) } \\
\text { (kg CO } 2 \text { eq.) }\end{array}$ & 29746 & 23349 & 24032 \\
\hline Acidification, emissions (g SO eq.) & 177857 & 140064 & 144359 \\
\hline Volatile organic compounds (g) & 262 & 210 & 217 \\
\hline Persistent organic pollutants (POP) & 5455 & 4522 & 4886 \\
\hline Heavy metals (mg Ni eq.) & 23598 & 21112 & 25216 \\
\hline PAHs (mg Ni eq.) & 1590 & 1306 & 1344 \\
\hline Particulate matter (g) & 4488 & 4172 & 4362 \\
\hline
\end{tabular}

\begin{tabular}{|l|c|c|c|}
\hline Emissions into water & SynRM & PMSynRM & IM \\
\hline Heavy metals (mg Hg/20) & 7730 & 6784 & 6883 \\
\hline Eutrophication (g PO4) & 146 & 142 & 165 \\
\hline
\end{tabular}

(1) Gross energy requirement

(2) Global warming potential

It should be noted that in Table 4 a loss-based environmental impact analysis is presented; in this paper an electric motor is defined as an energy converter (not as an end-use device).

In Fig. 3, greenhouse gas exemplary curves are shown. Greenhouse gases are those that absorb and emit infrared radiation at the wavelengths emitted by the Earth. More information about emissions taken into account in this paper is given in the Appendix.

As follows from Table 5, the use stage completely dominates over the lifecycle impact of electric motors; it is directly dependent on the efficiency of the designed motor. This stage involves many processes from the ecological and economic points of view. 




Use

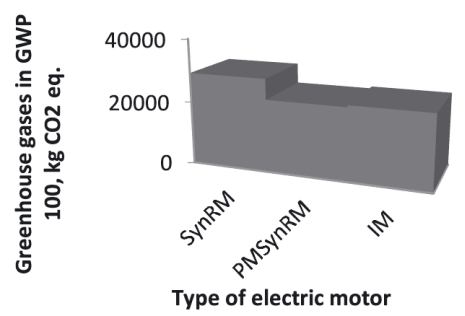

Distribution



End of life



Fig. 3. Greenhouse gases $v s$. the type of electric motor at four lifecycle stages.

At the distribution stage, the MEEuP model assumes a distance of $200 \mathrm{~km}$ for the first trip from manufacturer (or retailer) to the installation site [6], but not the distance covered by trips for repair and maintenance of the motor.

Table 5

Environmental Impact Made by the Motors at Different Lifecycle Stages

\begin{tabular}{|l|c|c|c|c|}
\hline Type of motor & Production, \% & Distribution, \% & Use, \% & End of Life, \% \\
\hline SynRM & 1.404 & 0.017 & 98.515 & 0.064 \\
\hline PMSynRM & 1.807 & 0.21 & 98.086 & 0.086 \\
\hline IM & 1.980 & 0.21 & 97.9 & 0.100 \\
\hline
\end{tabular}

\section{CONCLUSION}

From the four stages of the motor lifecycle described above, the production stage is less costly for the synchronous reluctance motor, as there are no high-energy magnets and the rotor is without winding. Respectively, the raw materials used in production are cheaper and less influential for environment. However, this type of motor produces a huge amount of waste during the use stage due to its low efficiency. Motors with low efficiency have high utilisation costs and high emissions in the environment. As far as the PMSynRM is concerned, it should be noted that, although the use of permanent magnets makes this design expensive and heavy, still in their operation this type of motors inflicts little damage to the environment during the usage phase.

Based on the results of the comparative analysis, the conclusions are as follows. 
1. The LCA allows comparing different products and determing which of them is more environmentally friendly not only during the production phase, but also taking into account the entire lifecycle period.

2. In the future, it is not possible to produce the product without being aware of the product impact on the environment. The producers should know what happens before and after the production stage at a factory.

3. The assessment of the expected environmental impact should be performed at the early design stage, which would allow decreasing the harmful emissions into the atmosphere.

4. The PMSynRMs are the most expensive motors in terms of production, while at the use stage they exert little environmental impact.

\section{ACKNOWLEDGEMENTS}

The present research has been supported by the Estonian Research Council under grant PUT1260.

\section{REFERENCES}

1. Waide, P., and Brunner, C. U. (2011). Energy-Efficiency Policy Opportunities for Electric Motor-Driven Systems. Working paper. International Energy Agency. Energy Efficiency Series.

2. IEC. (2014). IEC 60034-30-1:2014: Rotating Electrical Machines - Part 30-1: Efficiency classes of line operated AC motors (IE code). p. 50 .

3. ISO. (2006). ISO 14040:2006 - Environmental Management: Life cycle assessment. Principles and framework. p. 20.

4. ISO. (2006). ISO 14044:2006 - Environmental Management: Life cycle assessment. Requirements and guidelines. p. 46.

5. EuP Network Website. [Online]. Available at http://www.eup-network.de/updates/

6. de Almeida, A. T., Ferreira, F. J. T. E., Fong, J., and Fonseca, P. (2008). EUP Lot 11 Motors. Coimbra.

7. Vaimann, T., Kallaste, A., Kilk, A., and Belahcen, A. (2013). Lifecycle-based design and optimization of electrical motor-drives: Challenges and possibilities. In 3rd International Conference on Electric Power and Energy Conversion Systems (pp. 2-5).

8. Lehtinen, H., Saarentaus, A., Rouhiainen, J., Pitts, M., and Azapagic, A. (2011). A Review of LCA Methods and Tools and their Suitability for SMEs List of Contents. [Online]. Available at http://www.biochem-project.eu/download/toolbox/sustainability/01/120321\%20BIOCHEM\%20LCA_review.pdf

9. Williams, A. S. (2009). Life Cycle Analysis: A Step by Step Approach. ISTC Reports. Illinois.

10. Andrada, P., Blanqué, B., Martínez, E., Perat, J. I., Sánchez, J. A., and Torrent, M. (2012). Environmental and life cycle cost analysis of one switched reluctance motor drive and two inverter-fed induction motor drives. IET Electric Power Applications 6 (7): $390-398$. 


\section{APPENDIX}

Greenhouse gases (GHGs): a group of gasiform compounds, which are components of the Earth atmosphere. They practically do not pass through the thermal radiation coming from our planet. The following compounds are included into the GHG list: water vapour, carbon dioxide $\left(\mathrm{CO}_{2}\right)$, nitrous oxide $\left(\mathrm{N}_{2} \mathrm{O}\right)$, perfluorocarbons (PFCs), hydrofluorocarbons (HFC), sulphur hexafluoride $\left(\mathrm{SF}_{6}\right)$.

Acidification: caused mainly by emitting the oxidizing substances - ammonia $\left(\mathrm{NH}_{3}\right)$, sulphur oxide $\left(\mathrm{SO}_{2}\right)$, and nitrogen $(\mathrm{N})$. The emissions of the acidifying substances cause serious damage to the environment and humans.

Volatile Organic Compounds (VOCs): the chemical substances emitted to the atmosphere, in combination with nitrogen oxide $(\mathrm{NO})$ and ozone $\left(\mathrm{O}_{3}\right)$. These are chemical substances whose initial boiling point measured at the standard pressure is $101.3 \mathrm{kPa}$ or $250^{\circ} \mathrm{C}$.

Persistent Organic Pollutants (POPs) are the primary or by-products of the industry. Nowadays, 12 substances are designated as POP: polychlorinated biphenyls $\left(\mathrm{C}_{12} \mathrm{H}_{4} \mathrm{Cl}_{4} \mathrm{O}_{2}\right)$ and furans $\left(\mathrm{C}_{4} \mathrm{H}_{4} \mathrm{O}\right)$, polychloride biphenyls $\left(\mathrm{C}_{12} \mathrm{H}_{10-\mathrm{n}} \mathrm{Cl}_{\mathrm{n}}\right)$, DDT $\left(\mathrm{C}_{14} \mathrm{H}_{9} \mathrm{Cl}_{5}\right)$, chlordan $\left(\mathrm{C}_{10} \mathrm{H}_{6} \mathrm{Cl}_{8}\right)$, heptachlor $\left(\mathrm{C}_{10} \mathrm{H}_{5} \mathrm{Cl}_{7}\right)$, hexachlorbenzene $\left(\mathrm{C}_{6} \mathrm{Cl}_{6}\right)$, toxaphene $\left(\mathrm{C}_{10} \mathrm{Cl}_{12}\right)$, aldrin $\left(\mathrm{C}_{12} \mathrm{H}_{8} \mathrm{Cl}_{6}\right)$, dieldrin $\left(\mathrm{C}_{12} \mathrm{H}_{8} \mathrm{Cl}_{6} \mathrm{O}\right)$, endrinimirex. As a rule, the POPs have common characteristics: they are low-volatile chemically stable compounds, which are able to remain in the environment for a long time without being decomposed.

Heavy metals and their compounds stand out within the various polluting substances by prevalence, high toxicity, many of them also by the ability to bioaccumulation. They are widely used in various industries, so despite the clean-up procedures the content of heavy metals in the industrial wastewater is rather high. They also enter the environment from the domestic wastewater, smoke and dust of industrial enterprises.

Polycyclic aromatic hydrocarbons (PAHs) are high molecular weight organic compounds of the benzene series, differing in the number of benzene rings (2 to 7). The technology-related PAHs are formed during the combustion of fossil fuels in the industry and energy economy when producing coke or operating the internal combustion engine.

Eutrophication is the saturation of water reservoirs with biogenic elements, accompanying the increase in the biological productivity of water reservoirs. The eutrophication can be a natural result of the aging of the reservoir, as well as due to anthropogenic impacts. The main chemical elements contributing to the eutrophication are phosphorus $(\mathrm{P})$ and nitrogen $(\mathrm{N})$. 


\section{DZĪVES CIKLA ANALĪZE DAŽĀDIEM DZINĒJIEM NO IETEKMES UZ VIDI VIEDOKL̨,A}

S. Orlova, A. Rassõlkin, A. Kallaste, T. Vaimann, A. Belahcen

\section{Kopsavilkums}

Dzīves cikla salīdzinājuma analīze tiek veikta dažādiem dzinējiem no to kaitīgās ietekmes uz vidi viedokḷa. Tiek apskatīti trīs ǵeneratora tipi: sinhronais reaktīvais dzinējs, sinhronais reaktīvais dzinējs ar pastāvīgajiem magnētiem un asinhronais dzinējs. Dzīves cikla analīze tiek izpildīta četriem etapiem: izgatavošana, sadale, izmantošana un dzīves beigas. Rezultāti parāda, ka sinhronais reaktīvais dzinējs ir lētāks izgatavošanā, nekā dzinējs ar pastāvīgajiem magnētiem, bet, pateicoties zemajam lietderības koeficientam, kait̄̄gāk ietekmē vidi. Galvenais secinājums ir tāds, ka dzīves cikla novērtējums ir jāveic agrā projektēšanas stadijā, lai samazinātu ietekmi uz vidi

21.11.2016. 